\title{
COGNITIVE POTENTIAL AND JOB COMPLEXITY AS PREDICTORS OF FLOW
}

\author{
G PERCIVAL \\ F CROUS \\ $\mathrm{J}$ M SCHEPERS \\ Programme in Industrial Psychology \\ Department of Human Resource Management \\ Rand Afrikaans University
}

\begin{abstract}
The purpose of this study was to establish the extent to which flow can be predicted by the cognitive potential of the incumbent and the complexity of the work he/she performs. The sample consisted of 161 participants from a telecommunications company. The Flow Experience Survey (FES) was adapted and administered to the respondents. The Initial Recruitment Interview Schedule (IRIS) was used to measure capability and the Matrix of Working Relationships was used to measure job complexity. The FES and IRIS scales were subjected to factor analysis. An item analysis was also performed on the FES to determine the reliability of the instrument. There was a statistically significant relationship between capability and job complexity, but these variables did not relate to the flow experience. The implications of these findings are discussed.
\end{abstract}

\section{OPSOMMING}

Die doel van die studie was om te bepaal in watter mate psigiese "vloei" voorspel kan word deur die kognitiewe potensiaal van die posbekleër en die kompleksiteit van die werk wat hy/sy verrig. Die steekproef het uit 161 deelnemers van 'n telekommunikasie organisasie bestaan. Die "Flow Experience Survey" (FES) is aangepas en daarna toegepas op die deelnemers. Die "Initial Recruitment Interview Schedule" (IRIS) is gebruik om kognitiewe potensiaal te meet, terwyl die "Matrix of Working Relationships" gebruik is om die kompleksiteit van werk te bepaal. Sowel die FES as IRIS skale is onderwerp aan ' $n$ faktorontleding. Verder is ' $n$ itemontleding uitgevoer op die FES om die betroubaarheid daarvan te bepaal. 'n Statisties beduidende verband tussen kognitiewe potensiaal en die kompleksiteit van werk, is gevind, alhoewel hierdie veranderlikes nie met "vloei" verband gehou het nie. Die implikasies van die studie word bespreek.

The key to human happiness is loving one's everyday profession (Csikszentmihalyi, 1975). For most people, work occupies a considerable portion of their life span and goes beyond influencing behaviour; it plays a major role in the sense of self (Deci \& Ryan, 1985). A vast body of disjointed and unfocused literature relates directly or indirectly to intrinsic motivation in the workplace (Alderfer, 1972; Herzburg, 1966; McGregor, 1960; McClelland, 1965). Each of these approaches has proven useful in practice, but tends to overlook aspects of intrinsic motivation considered important by the other.

Intrinsic motivation is of considerable importance to organisations and employees alike, given that the employee's experience of work, be it emotional, psychological, or physical in nature, affects their performance (Daniels, 2000). Also, according to Danna and Griffin (1999), the true breadth of the consequences and costs of impaired motivation to employees and organisations is becoming apparent. Deci and Ryan (1985) consider intrinsic motivation, or engaging in a task for its enjoyment value, one of the most powerful forms of motivation. Therefore there is an impetus for new research into the meaning, determinates and consequences of work on the individual.

The goal of positive psychology is to enhance experiences of work, love and play (Wellner \& Adox, 2000). One such approach explores positive experiences and this is the construct of "flow" proposed by Csikszentmihalyi (1975). In contrast to his contemporaries, he places greater emphasis on enjoyment as a key component to an intrinsically motivated activity. Whenever people do something that they enjoy, they keep doing it because of the experience that they get from the activity itself (Wellner \& Adox, 2000). According to Csikszentmihalyi (1975) flow is the positive experience created when challenges are congruent with the skills of the individual. It is this harmonious balance, between skill and challenge that creates what is known as flow.

Requests for copies should be addressed to: F. Crous, Department of Human Resource Management, RAU University, PO BOX 524, Auckland Park, 2006
Csikszentmihalyi (1975) became interested in people who repeated an activity or performed best when they engaged in an activity that they enjoyed. Often these activities require considerable time, effort and skill yet produce little financial status or compensation (Allison \& Duncan, 1988; Csikszentmihalyi, 1990). Csikszentmihalyi (1975) studied activities such as composing music, hobbies, playing chess, sports, surgery, dancing, and rock climbing, which all share a common autotelic function, that is, they provide an experience that is intrinsically rewarding. Common to all these autotelic experiences is the matching of personal skills and a meaningful challenge. This provides the experience of a deep sense of enjoyment and focused attention on an activity (Csikszentmihalyi, 1975). People who have experienced flow want to replicate the activity, regardless of whether the activity provides material rewards or not (Csikszentmihalyi, 1990).

Therefore, flow, as defined by Csikszentmihalyi (1975, 1993, 1988, 1990), is a temporary condition characterised by a deep sense of concentration and enjoyment on a specific activity when skill and challenge are balanced. Hence, flow is a holistic sensation that people experience when they act with total involvement in what they do.

Studies of Csikszentmihalyi (1975, 1990, 1993, 1997,1999) and Csikszentmihalyi and Csikszentmihalyi (1988) have identified eight fundamental components to the flow experience. First, the experience occurs because the task at hand has a chance of completion. Second, there is a balance between the perceived challenges and perceived skills of the person. Third and fourth, the awareness of self and action merge for focus. This is because clear goals are coupled with immediate and unambiguous feedback. Fifth, there is concentration on the task on hand. Sixth, a sense of a loss of self-consciousness follows. Seventh, the time becomes distorted, as it is perceived as faster. Finally there is a sense of potential control, as skill significantly reduces the margin of error. The combination of these elements creates a sense of enjoyment to the extent that considerable energy is 
expended to be able to re-experience flow. Therefore the two key characteristics of flow are: firstly, total concentration over the activity where enjoyment is derived and secondly, the more salient element is a sense of control over the environment (Csikszentmihalyi, 1975; Deci \& Ryan, 1985; Ghani \& Deshpande, 1994).

To explain flow, Csikszentmihalyi (1975) originally proposed a three-channel flow model. Flow is portrayed as state of wellbeing, or optimal experience when both skills and challenges are matched. This degree of congruence ranged from high to low. However, greater empirical support has been found for the reformulated four-channel flow model, where flow is defined as a high skill and high challenge combination, and apathy is experienced when both skill and challenge are low (Massimini \& Carli, 1988). It is important to recognise that these models do not contradict each other, but merely adapt to new research findings (Novak \& Hoffman, 1997). A natural extension of the four-flow channel model is the eight-flow channel model, which allows for moderate balances of skills and challenges (Massimini \& Carli, 1988).

The experience of flow can therefore also be conceptualised along a continuum that ranges from micro-flow to deep flow experiences. Micro-flow activities are essentially both low in skill and challenge, but are an important facet in everyday life as demonstrated in the flow deprivation study (Csikszentmihalyi, 1975). Research has revealed that individuals who frequently experience flow, as a consequence, are more likely to have higher levels of motivation, concentration, cognitive efficiency, activation, enhanced performance and better psychological and physical health (Csikszentmihalyi \& Csikszentmihalyi, 1988; Csikszentmihalyi, 1990; Deci \& Ryan, 1985; Larson, 1988). These people are also more alert, energetic, creative, competent, and able to make sound decisions (Csikszentmihalyi, 1990; Stamp, 1989).

Therefore, flow may be operationalised in terms of three sequential phases: firstly, the structural properties of flow (clear goals, balanced skills and challenge); secondly, the experience of flow (loss of self- consciousness, passing of time), and finally the antecedents of flow, which is a sense of intrinsic enjoyment (Csikszentmihalyi \& Csikszentmihalyi, 1988; Novak \& Hoffman, 1997).

Regardless of age, gender, ethnic or cultural origin, it is suggested that the experience of flow is universal. However, Allison and Duncan (1988) and Csikszentmihalyi $(1975,1997)$ conclude that older people, females and those with higher socioeconomic standing and education all derived more enjoyment in an activity, and therefore are more predisposed to the flow experience than their counterparts. This mirrors Maslow's hierarchy of needs in which a person cannot be concerned with self-actualisation until primary needs have been met. However, the research of Anderson, Crous and Schepers (1996) found that there are no significant differences between males and females with respect to the flow experience.

\section{Flow at work}

The overwhelming proportions of flow experiences occur when the sequence of activities are goal directed and cannot be accomplished without the appropriate skills. A research finding of LeFevre (1988) suggests that work, rather than leisure, is more amenable to the experience of flow. This is because work provides a high-challenge, high-skill context and is accompanied by feelings of concentration, creativity and satisfaction (Csikszentmihalyi \& Csikszentmihalyi, 1988).

It makes sense to think that the quality of the flow experience when working could depend on the type of job one has, but the characteristic nature of work persists despite job differences (Csikszentmihalyi, 1997). There also seems to be a relationship between flow and well-being on and off the job. This is because flow correlates to degrees of job satisfaction and life satisfaction (Carli, Della Fave \& Massimini, 1988). The design of the job is also considered an important contributor to employees' level of intrinsic motivation (Judge, Bono \& Locke, 2000). Complex, challenging jobs (those characterised by skill variety, identity, significance, feedback and high levels of autonomy) specifically tend to support and encourage higher levels of intrinsic motivation (Oldham \& Cummings, 1996).

The complexity of the flow activity depends on the gradient of challenges and the difficulty of the skills required, for example, surgeons who repeatedly perform the same routine operation often experience boredom (Csikszentmihalyi \& Csikszentmihalyi, 1988). Research by Massimini and Carli (1988) revealed that in order to experience flow, there must be a unity between challenge and skill and this needs to be above a critical threshold level. To remain in flow, one must increase the complexity of the activity by developing both new challenges and skills (Csikszentmihalyi \& Csikszentmihalyi, 1988). At work, it is desirable to have a match between the individuals growing capabilities and increasing work responsibilities. When this is achieved, the individual is more likely to remain in flow in the longer term. This is important because little research has focused on the maintenance of well-being over the long term (Lu, 1999). In the opinion of Larson (1988), it is the ability to structure experience to provide a balance between challenge and skill at a higher level of complexity that leads towards personal growth and discovery. This suggests that flow is an optimal experience that facilitates the fulfilment of individual potential.

Privette (1983) contrasts the experience of flow to Maslow's concept of self-actualisation, called peak experiences. Peak experiences are characterised by moments of happiness and fulfilment. She suggests that flow is a combination of enjoyment derived from peak experiences and the behaviour from peak performance. However, the achievement of a goal, as in selfactualisation, is not essential in order to experience flow (Privette, 1983). Maslow's self-actualisation refers to fulfilling ones potential, whereas flow is the process of becoming involved in an activity. Flow per se does not imply optimal joy or performance but may include either or both (Privette \& Bundrick, 1987).

The value of this knowledge will assist in altering job descriptions so that they are more enjoyable and create conditions that will be more conducive to flow. The organisation will also derive benefit from the spin off of the intrinsic motivation and improved performance of employees. An important assumption is that flow experiences lead to an increase in productivity (Anderson, et al. 1996; Csikszentmihalyi, 1990; Loubris, Crous \& Schepers, 1995; Lu, 1999).

\section{Anxiety}

Due to the fact that the experience of flow is operationalised as the unity between challenge and skill, a sense of anxiety or stress is produced when challenges are higher than the individual's skill or ability (Xie \& Johns, 1995). Conversely, boredom is experienced when skills are higher than the challenge of the task (Privette, 1983). Flow is therefore poised between boredom and anxiety (Csikszentmihalyi, 1975).

It is suggested that the relationship between challenge and wellbeing is curvilinear rather than linear. This is because stress occurs when the job was either too complex or simple for the incumbent's preference (Xie \& John, 1995). A further factor that needs to be taken into account in sustaining flow is that neither capabilities nor challenges remain static. If the challenges overwhelm a person's capabilities, the person is more likely to withdraw by leaving the organisation, or redraw their roles by only concentrating on tasks they are comfortable with. This results in the person not necessarily meeting the organisational needs (Stamp, 1991; Stamp \& Stamp, 1993). The person passes through the states of perplexity, to worry and finally to anxiety. 
This is illustrated in Figure 1.

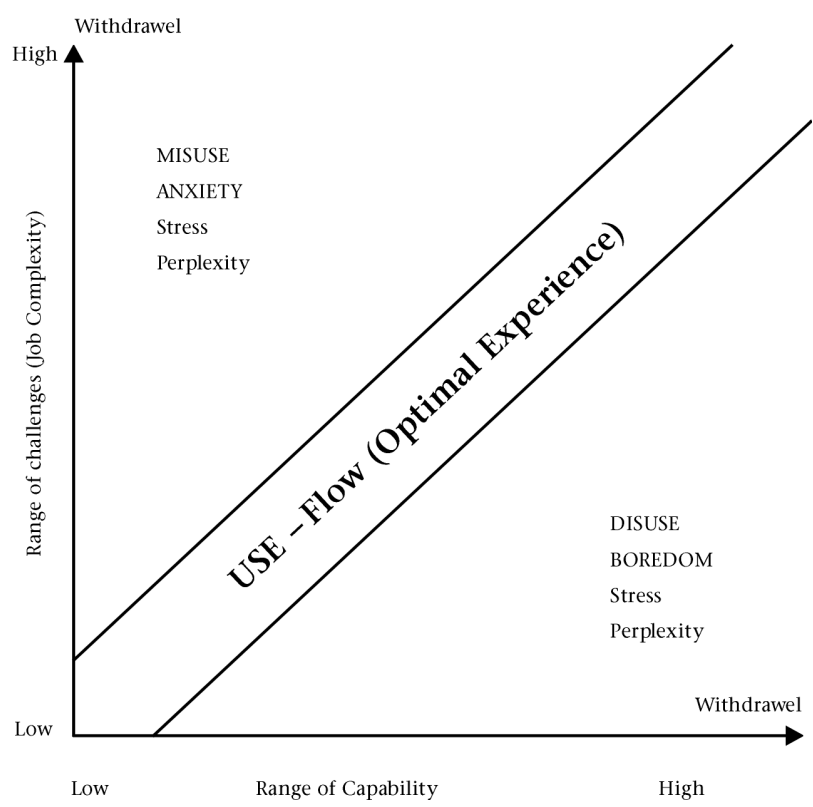

Figure 1: Diagrammatical Representation of the experience of work and flow (Adapted from Csikszentmihalyi, 1975; Stamp \& Stamp 1993)

Stress and anxiety are likely to be experienced when an individual perceives an imbalance between coping capabilities and the demands made on them (Stamp, 1991). Larson (1988) refers to excessive challenge for the individual's skills as over arousal. This is characterised by emotions or feeling of being overwhelmed and this typically results in disintegration of thoughts and attention. The cost of stress at work is only too well known. Often not amenable to measurement is the human costs of confusion and distress for the individual, the cost of poor judgement, low morale, resistance to change and the inevitable performance decline (Stamp, 1991).

\section{Boredom}

Boredom classically occurs when there is no challenge in a task to meet the skills of the individual (Csikszentmihalyi, 1990; LeFevre, 1988). Thus, a task significantly below the capabilities of the individual will result in frustration due to the ease of the task. Larson (1988) describes this as under-arousal, a state of apathy, disinterest and boredom. Allison and Duncan (1988) coined the term "antiflow", which is the antithesis of flow, to describe a meaningless state of tedious activity with little challenge or motivation.

Although contradictory, boredom is intrinsically connected to too little or too much stimulation in one's work (Gimmel \& Oakley, 1992). Fisher's (1998) research indicated that people are bored when their work had simple, repetitive tasks requiring low mental demands. Boredom was also experienced when the task was too difficult. Stimulating work can be meaningless or overwhelming if too many possibilities exist with no clear rationale for choice (Gimmel \& Oakley, 1992).

Paradoxically, repetitive work, per se, is not necessary boring. It can be considered meaningful by others, resulting in the experience of flow (Gimmel \& Oakley, 1992) Thus, an optimal level of challenge, which is neither too difficult, nor too easy, is imperative to engage and sustain attention (Fisher, 1998). The relationship between skill and boredom is moderated by task complexity. Thus, the nature of the task is not necessary a determinate of the flow experience (Csikszentmihalyi, 1990; Fisher, 1998).

Evidence suggests that boredom can have adverse consequences such as daydreaming, irritability, stress, hostility, poor decisionmaking, sleepiness, taking longer to notice and correct errors, increased risk-taking behaviour and automatic solutions (Damrad-Frye \& Laird, 1989; Stamp \& Stamp, 1993; Fisher, 1998). Over the longer term, boredom may be associated with job dissatisfaction and absenteeism (Fisher, 1998). A state of anxiety may be reached after prolonged boredom as there is a perception that current capabilities might be lost (Stamp, 1991). This is illustrated in Figure 1. Boredom has a number of implications for the organisation, such as not optimal utilisation of talent, reduced level of productivity as work is increasingly perceived as a chore (Stamp, 1991). The employee may also eventually withdraw from work and focus on activities outside their employment (Stamp \& Stamp, 1993).

Flow requires a balance between challenges and skills. It is because of this balance that flow takes place in structured activities in which the level of challenges and skills can be varied and controlled (Csikszentmihalyi, 1990). No previous empirical research has investigated the link between the structured characteristics or contexts that contribute to an employee's flow experience. However, there is theoretical support for such a link. The psychological experience of flow is made possible by the configuration of the objective preconditions, that is, a balance between skill and challenge. Previous research (Allison \& Duncan, 1988; Carli \& Massimini, 1988; LeFevre, 1988) conducted on flow is limiting, because the structural properties of Csikszentmihalyi's flow model are based on a very general subjective evaluation of the respondents' perceived skills and perceived challenge. This means that the respondents' perception of their skill and challenge will vary depending on the occasion. This measurement of flow could therefore be capturing the respondent's trait or state (Novak \& Hoffman, 1997). This subjective evaluation of the objective structure of flow has also resulted in skill and challenge measures being conceptually distinct and not amenable to comparison between individuals.

The primary focus of the study is the transition from theory to empirical validation of Csikszentmihalyi's flow model. To achieve this, the flow model is embedded into Stratified Systems Theory. This theory has the advantage of being amenable to the extrapolation of the construct of flow into a more theoretical form and provides a framework for ensuring the maintenance of flow conditions in the future. Stratified Systems Theory also provides a common point for comparison between individuals.

\section{Stratified Systems Theory}

Jaques (1970) proposed Stratified Systems Theory, hereafter SST. This theory proposes that work is structured in levels of increasing complexity within any organisation (Stamp, 1988). Jaques (1970, 1996) identified seven levels of work, with each level adding value in a unique way to the organisation. Levels of work are based on the premise that as one progresses up the hierarchy, the complexity of the work increases. Each level is more complex that the one below it and therefore poses unique new conceptual requirements for decision-making (Stamp, 1989; Jaques, 1970, 1996). The increasing complexity of each level results in a longer time horizon before one can see the results or fruits of successful decision-making. There are also more variables to consider, some of which are intangible (Jaques, 1970). Therefore, work has a time span and this is the quantitative measure of job complexity. Also, the longer the time span, the higher cognitive capability required (Jaques, 1970, 1989, 1996; Stamp, 1993). This means that the higher echelons in the organisation require greater cognitive skills than the lower levels (Jaques \& Cason, 1994; Stamp \& Retief, 1996). Evidence to support the relationship between time span and level of work is presented through the strong correlation between time spans and perceived fair pay. The correlation between measured time span in a role and a person's perceived fair pay ranged from 0,86 to 0,92 (Carraher \& Chait, 1999; Jaques, 1989).

This hierarchy of complexity has no connotations of command and control structures, but refers to quantitative increases in complexity (Olivier, 1999). One level is no better than another, 
as each level is vital and has a different role to play within the organisation. The lowest level in the organisation is well configured and has more concrete goals than the higher levels (McIntyre et al, 1994).

\section{Capability}

Capability is the combination of competencies that enable an individual to work and achieve goals. It is comprised of a person's cognitive capability, which is their ability to process and organise information (Stamp, 1988). However, cognitive capability is only one of the attributes that form a person's ability to work. Other attributes include knowledge, skills, experience and temperament (Jaques, 1989, 1970). The concern here is cognitive functioning. This does not mean that the importance of skills and experience are denied, as they become tools to support judgement. Focusing on skills alone tends to reflect "static" differences between individuals rather than differences in individual capability (McIntyre, Yanusefski \& Hamill, 1994; Stamp, 1988). Assumptions of individual capability should never be made on the basis of qualifications or demonstrated skill alone. This is of special significance in the context of South Africa, as large sectors of the population are poorly educated (Stamp \& Retief, 1996). A longitudinal study conducted by Stamp (1988) suggests that development beyond lower and middle levels within the organisation is heavily dependent on conceptual ability rather than knowledge-based instruction.

Therefore, capability, in this context, is the complexity of the world in which one is able to pattern, construe and function. This includes the amount and the complexity of information that must be processed (Jaques, 1989, 1998). Jaques (1998) clearly distinguishes between potential capability and applied capability. Potential capability is the very highest level in which a person could work, whereas applied capability is the level at which the person is actually working (Jaques, 1998).

Cognitive capability becomes important when assessing the level of work or responsibility that the person is capable of (Jaques, 1970, 1989). The theory is also based on the hypothesis of rates of the growth of an individual's capability to exercise discretion and therefore to do work at increasing levels of complexity in the future (Stamp, 1988; Stamp \& Retief, 1996). SST also supports discontinuity in the development of cognitive processes. Therefore SST departs from current views in two important respects: firstly, it does not associate cognitive development with particular ages, and secondly, individuals may mature in cognitive development along the same band or path, but some may progress faster than others (Jaques, 1986, 1989, 1998). This means individuals change to different states as they reach different points of cognitive capability, and this is measured in time horizons rather than particular ages (Jaques, 1986). Each level is associated with a different degree of cognitive ability. Research findings support the existence of growth processes based upon the individual's initial assessed capability and chronological age (Mauer, 2000).

The essence of using discretion is what a person does when there is no clear alternative, and this is the prime focus in the assessment of capability (Retief \& Stamp, 1996). It is time span that differentiates between the various levels of capability. The longer the time span a person can achieve, the higher his or her level of capability.

\section{Job complexity}

Work of a greater complexity is typically distinguished by high degrees of uncertainty, low divisibility of activities, more abstract rather than concrete activities, and less repetition (Kivimaki, Kuk, Elovaninio, Thomson, Kalliomaki-Levanto \& Heikkila, 1997). The SST considers the complexity of the work that the organisation demands of the incumbent occupying the post.

The Dictionary of Occupational Titles (DOT) evaluates job complexity by considering the degree of synthesizing, coordinating, analysing and comparing of information. Vocational preparation and on-the-job intelligence is also measured. As stated by Ganzach (1998, p. 531) "the reliance on this measure can be questioned on the grounds that it includes the job analysts' judgements of required education and aptitude." An advantage of the DOT method is that the data is based on extensive on-site observation of the job (Gerhart, 1988). In comparison, the Job Diagnostic Scale (JDS), based on Hackman and Oldham's Job Characteristic Model, evaluates job complexity in terms of variables such as autonomy, feedback and task identity. This measure tends to confound personal needs and preferences of the performer with the objective characteristics of the task (Gerhart, 1988; Hackman \& Oldham, 1980). It also confounds job characteristics with job complexity. Literature clearly shows that perceptual measures of intrinsic job characteristics are not directly related to job complexity (Adelmann, 1987). However, research by Judge et al. (2000) provides evidence that job characteristics do relate, to an extent, to job complexity. Specific job characteristics (e.g. skill variety, task significance) lead to psychological satisfaction, characterised by feelings of meaningfulness and responsibility, which in turn lead to satisfaction on the job (Judge, et al. 2000).

Job complexity has been considered an important contributor to outcomes of happiness or a general positive effect, creativity and intrinsic motivation (Adelmann, 1987; Oldham \& Cummings, 1996). Other studies that examine the relationship between job complexity and well-being are restrictive because they tend to focus on homogenous samples of lower level occupations (Adelmann, 1987; Ganzach, 1998).

People have a tendency to gravitate towards jobs that are commensurate with their abilities. This statement is consistent with Holland's (1985) view that within a given class of occupations, the level of occupational choice is likely to be more successful if the individual has the right talents and abilities to meet the demands of the job. Bandura's theory of self-efficacy clearly predicts that individuals' beliefs about their capabilities to perform a task will influence their motivation to seek or avoid the task (Bandura, 1997). As asserted by Bandura (1997), people tend to avoid activities and environments that they believe exceed their capabilities but readily choose those activities that they judge they are capable of handling. This is reinforced through the fact that people are continuously drawn to positions that fit them well - that is positions that are neither too simple nor too challenging. The true fit between a person and a job depends on the match between the "time span" of the job and the capabilities of the person (Jaques, 1996). There is a gravitational process in which people gravitate towards jobs that are commensurate with their abilities (Ganzach, 1998).

The aim of the study was to validate the theoretical proposition of the structure of flow by quantifying the measures of skill (capability) and challenge (job complexity), and to further establish whether these variables contribute to the flow experience. The problem of the study may be stated as follows: To what extent can flow be predicted by measures of the cognitive potential of the incumbent and the job complexity of the work he/she performs?

The following research hypotheses were formulated:

Hypothesis 1:

There is a statistically significant positive relationship between the index of cognitive potential of the incumbent and the complexity of the work he/she performs.

The rationale for this hypothesis is that people tend to gravitate to work that is commensurate with their abilities (Bandura, 1997; Holland, 1985). Capability may be related to the complexity of the jobs that people hold and the complexity of the work they desire. Jobs differ in their level of complexity and the levels of capability required. This means that people of higher 
capability will cope better with jobs of higher complexity, conversely people of lower capability will be able to cope with lower complexity work (Jaques, 1970).

\section{Hypothesis 2:}

There is a statistically significant positive relationship between the index of complexity of the work that the incumbent performs and the experience of flow.

Individuals are more likely to have positive experiences doing complex, challenging work (Oldham \& Cummings, 1996). Jobs that are challenging and complex are also associated with feelings of general positive affect (Adelmann, 1987).

\section{Hypothesis 3:}

There is a statistically significant positive correlation between the balance of capability and job complexity on the one hand and the experience of flow on the other.

The rationale for this hypothesis is that capability must be balanced with job complexity to create objective conditions conducive to the subjective experience of flow. It is the interaction between the objective and subjective states that creates optimal experience.

\section{Hypothesis 4:}

There are statistically significant differences between the vectors of means of the groups listed below in respect of the flow variables. The groups are as follows:

- occupational categories (clerks, sales and technicians, professionals and management),

- ethnicity

- gender

- academic qualification categories (matric or less, diploma, degree, and post-graduate)

- length of service within the current organisation

Flow is hypothesised to be a universal experience, irrespective of occupation, ethnicity, gender, and qualification. However, research suggest that those people of higher socio-economic status, females and professionals are more likely to experience flow than their counterparts (Allison \& Duncan, 1988; Anderson, et al. 1996).

\section{Hypothesis 5:}

There are statistically significant differences between the means of the groups listed below in respect of the capability index. The groups are as follows:

- occupational categories (clerks, sales and technicians, professionals and management),

- academic qualification categories (matric or less, diploma, degree, and post-graduate)

- gender

- ethnicity

\section{METHOD}

\section{Sample}

The research was conducted in a telecommunications organisation. A convenience sample of 161 employees of diverse ages, education, level in the organisational hierarchy, and cultural background, participated in the study. Only employees who had undergone an Initial Recruitment Interview Schedule in the past twelve months were eligible to participate in the study.

The sample consisted of $50,3 \%$ males and $49,7 \%$ females. The average age of the respondents was 32,5 years - ranging from 20 to 56 years - with a standard deviation of 8,14 years. The level of education of the sample was as follows: $30,5 \%$ had a postgraduate qualification, $18,0 \%$ had a degree, $28,5 \%$ was in possession of a diploma, $23 \%$ of the sample had matric or less.
Of the sample, $66,5 \%$ were White, $13,7 \%$ were African, $11,2 \%$ were Asian, and $8,7 \%$ were Coloured. The Africans, Asians and Coloured groups were combined into one group for the purpose of statistical analysis. The respondents were divided in terms of their occupational category in the organisational hierarchy, as follows: Clerks 19,3\%; Sales and Technicians 26,7\%; Professionals 35,4\%, and Management 18,7\%. The respondents with less than one-year work experience in the present organisation comprised $24,8 \%$ of the sample. Those with more than one year, but less than three years comprised $28,0 \%$ of the sample. Those respondents with more than three years, but less than five years experience comprised $24,8 \%$ of the sample, and those respondents with more than 5 years work experience comprised $22,3 \%$ of the sample.

\section{Measuring Instruments}

Flow Experience Survey

It is based on the work of Csikszentmihalyi (1975, 1990, 1993). His flow construct provided the basis for a questionnaire known as the Flow Experience Survey (FES), designed by Anderson, et al. (1996). The questionnaire originally comprised 56 items, and each item was rated on a seven-point scale. The questionnaire consists of two scales, viz. Enjoyment and Control of Consciousness. The first scale, Enjoyment, has a reliability of 0,946 according to Cronbach's coefficient alpha, and the second scale, Control of Consciousness, a coefficient of 0,829 (Anderson, et al. 1996). All the questions in the survey are job related. The questionnaire consists of three sections, firstly biographical data, secondly instructions and finally the actual survey. However, the validity of the survey was not optimal as only six items loaded on the Control of Consciousness factor. Therefore, the researchers refined the FES by adding 13 items to this factor, in an attempt to better reflect the theory.

\section{Initial Recruitment Interview Schedule}

To measure individual capability, the Initial Recruitment Interview Schedule (IRIS) was used. The IRIS is based on the wellresearched procedure named Career Path Appreciation (CPA). Dr Shelia Rossan guided its development (Stamp, 1988, 1991). The IRIS explores the decision-making complexity that the individual is comfortable with. It does not solely rely on intelligence levels, cultural background or personality traits of the respondent but also refers to his or her preferred style of thinking. The IRIS is a one-to-one semi-structured interview that lasts about 45 minutes and allows a highly trained practitioner to arrive at an assessment of the person's capabilities (Stamp \& Stamp, 1993). This is achieved by a standardised scoring procedure. The IRIS gives a score of his/her current level of capability and a projected score for five, ten and fifteen years hence. It enables a judgement of the current level of capability and subsequent level of work that the individual is capable of. The predictions of capability are made on the basis of the initially assessed capability and chronological age. The IRIS can be used to identify candidates that are likely to be able to handle varying degrees of decision-making complexity (Mauer, 2000). It can be used at most levels within an organisation, ranging from semi-skilled staff to middle management.

The IRIS, in a study by Rossan and Baker (1997), yielded an acceptable interrater reliability of 0,84 for the total score. Their interrater reliability coefficients of the subscales of the IRIS range between 0,55 and 0,91 with a mean of 0,66 . The IRIS yielded a reliability coefficient of 0,69 according to Cronbach's coefficient alpha (Mauer, 2000). The Spearman-Brown split half coefficient, also yielded a value of 0,69 . Multiple correlation coefficients of 0,$86 ; 0,84 ; 0,77$ and 0,76 were found for the set of IRIS questions and current level of work for five, ten and fifteen years in the future (Mauer, 2000). Mauer (2000) concluded that the IRIS could be considered culture and gender fair, as there was no evidence to support bias on the basis of the distribution of the test scores. Furthermore, a factor analysis showed that only one factor represented the data structure (Mauer, 2000). 
The content validity may be described as acceptable as the IRIS was developed to represent the constructs of Stratified Systems Theory. Correlations between IRIS and CPA are statistically significant with coefficients ranging from 0,69 to 0,87 ( $p<0,05$ ) (Mauer, 1998). A South African investigation by Mauer (1998) provided evidence for construct validity. It was found that current capability correlated $(\mathrm{r}=0,25 ; \mathrm{p}<0,05)$ with verbal reasoning. At the ten years from date of the assessment, the IRIS correlated with verbal reasoning $(\mathrm{r}=0,38 ; \mathrm{p}<0,05)$, numerical reasoning $(\mathrm{r}=0,34, \mathrm{p}<0,05)$, and technical role-competence $(r=0,29, p<0,05)$ (Mauer, 1998). At the fifteen-year projection, the IRIS correlated with verbal reasoning $(\mathrm{r}=0,26, \mathrm{p}<0,05)$, numerical reasoning $(\mathrm{r}=0,29, \mathrm{p}<0,05)$, technical role $(r=0,40, p<0,05)$ and interpersonal skills $(r=0,30$, $\mathrm{p}<0,05$ ). These findings demonstrate adequate predictive validity, as well as construct validity as it is expected that there should be a degree of correlation between IRIS levels and cognitive abilities (Mauer, 2000). The face validity of IRIS is high as all the questions relate to past and current work-related experiences.

\section{Job Complexity}

In order to evaluate the complexity of work, the Matrix of Work Audit was used. The audit aims to establish where the work is located in respect of the different levels of complexity as identified by Jaques $(1970,1989,1996)$. The job incumbent is required to answer a series of questions relating to his or her work. Each job is then analysed according to the complexity of the job content required from the incumbent occupying the post. This means that numerous occupations could be found at the same level, depending on the complexity of the job's content.

Each job was evaluated according to the following dimensions:

1. Essential core job responsibilities and key performance areas unique to the position. This included task complexity, role complexity and leadership complexity.

2. Collaboration: this was both internal and external to the position. Internally this could refer to direct reports, colleagues and supervisors. External collaboration was with clients or industry bodies.

3. Discretionary space: this relates to decision-making discretion, creativity, vulnerability and time horizon.

There is cross verification of information with peers and managers to ensure the inherent consistency of the information gained and to ensure that the various elements confirmed and did not contradict one another (Stamp, 1993). A highly trained practitioner determines the complexity level. Experience has shown that a post often consists of several different levels of work. The purpose was to identify the level of work that is central to a job.

\section{Procedure}

The gathering of data was divided into three phases. Employees who had undergone an Initial Recruitment Interview Schedule in the past twelve months were eligible to participate in the study. These employees were pooled into one group. The second phase was the administration of the Flow Experience Survey (FES). The survey was accompanied by a covering letter detailing the purpose of the study and emphasising the anonymity and strict confidentiality of the data. The FES was presented in English and administered personally by the researcher with the assistance of the Human Resources Department. The final phase was the gathering of the job complexity levels. The organisation that participated in the study had adopted the SST model to classify their jobs into varying levels of complexity. This meant that information was readily available.

\section{RESULTS}

The 161 completed and useable IRIS and FES questionnaires returned were analysed statistically. Each of these scales will be discussed separately.
Flow Experience Survey (FES)

Initially, analyses were performed to determine whether the sample was adequate and if there was justification to perform a factor analysis on this scale. The Kaiser-Meyer-Olkin Measure of Sampling Adequacy (MSA) was $r=0,772$ and this was considered adequate for factor analysis. The result of Bartlett's test of Sphericity was $\chi^{2}(136)=673.04 ; p<0.001$. The significance of this test means that the variables are substantially mutually correlated and therefore provide the necessary justification to continue with the factor analysis.

The 69 items of the FES were intercorrelated and subjected to a factor analysis, which yielded 17 factors. This factor matrix was rotated to simple structure by means of Varimax rotation. As the intercorrelation matrix is of order $69 \times 69$, it is too large to be reproduced in this paper.

Next, subscores in respect of each of the 17 factors were computed. These subscores were intercorrelated and subjected to a factor analysis. Five factors were extracted and obliquely rotated to simple structure using the Direct Oblimin procedure (See Table 1). The matrix of intercorrelations between the five factors appears in Table 2 . Since the Measure of Sampling Adequacy was not optimal, an anti-image factor analysis was performed. This resulted in four subscores; 9, 14, 16 and 17 being discarded. These subscores each represented a single item that did not make a meaningful contribution. This analysis resulted in a twofactor solution (Table 3 ). The factors were identified as follows: Factor 1 as Enjoyment and Factor 2 as Control of Consciousness. Accordingly, two scales were formed. Scale 1 correlates 0,531 with Scale 2 . These factors were also found in the research conducted by Anderson, et al. (1996).

TABLE 1

ROTATED FACTOR MATRIX OF THE FLOW EXPERIENCE SURVEY (DIRECT OBLIMIN)

\begin{tabular}{lcrrrrr}
\hline Variable & Factor $\mathbf{1}$ & Factor 2 & Factor $\mathbf{3}$ & Factor 4 & Factor $\mathbf{5}$ & $\mathbf{h}^{\mathbf{2}} \mathbf{j}$ \\
\hline Subscore 3 & $\mathbf{0 , 6 8 1}$ & $-0,505$ & $-0,152$ & $-0,126$ & 0,075 & 0,871 \\
Subscore 15 & $\mathbf{0 , 6 4 4}$ & 0,050 & 0,042 & $-0,001$ & $-0,001$ & 0,424 \\
Subscore 1 & $\mathbf{0 , 6 3 8}$ & 0,103 & 0,315 & $-0,001$ & $-0,316$ & 0,779 \\
Subscore 4 & $\mathbf{0 , 5 3 3}$ & 0,305 & 0,001 & $-0,303$ & 0,286 & 0,663 \\
Subscore 14 & $\mathbf{0 , 2 2 4}$ & $-0,030$ & 0,024 & 0,069 & $-0,030$ & 0,053 \\
Subscore 5 & $\mathbf{0 , 2 0 1}$ & $-0,170$ & 0,191 & $-0,193$ & 0,060 & 0,236 \\
Subscore 17 & 0,096 & $\mathbf{0 , 5 5 1}$ & $-0,115$ & 0,114 & 0,140 & 0,384 \\
Subscore 16 & 0,076 & $-\mathbf{0 , 3 9 9}$ & 0,020 & 0,023 & 0,129 & 0,178 \\
Subscore 2 & 0,291 & 0,168 & $\mathbf{0 , 6 3 6}$ & $-0,198$ & 0,160 & 0,825 \\
Subscore 7 & $-0,010$ & $-1,001$ & $\mathbf{0 , 4 6 7}$ & 0,063 & $-0,010$ & 0,209 \\
Subscore 6 & 0,039 & $-0,139$ & $\mathbf{0 , 4 3 0}$ & 0,008 & $-0,005$ & 0,224 \\
Subscore 10 & 0,146 & $-0,020$ & $\mathbf{0 , 2 6 3}$ & $-0,153$ & 0,048 & 0,175 \\
Subscore 13 & $-0,090$ & 0,051 & 0,370 & $-\mathbf{0 , 5 3 5}$ & 0,114 & 0,476 \\
Subscore 9 & 0,069 & 0,173 & 0,178 & $\mathbf{0 , 4 9 8}$ & 0,133 & 0,358 \\
Subscore 8 & 0,005 & $-0,060$ & $-0,149$ & $-0,060$ & $\mathbf{0 , 7 3 5}$ & 0,488 \\
Subscore 11 & 0,126 & $-0,080$ & 0,192 & $-0,030$ & $\mathbf{0 , 4 8 7}$ & 0,423 \\
Subscore 12 & $-0,060$ & 0,063 & 0,158 & 0,178 & $\mathbf{0 , 4 1 5}$ & 0,253 \\
\hline
\end{tabular}

TABLE 2

MATRIX OF INTERCORRELATIONS OF THE FACTORS IN RESPECT OF THE FLOW EXPERIENCE SURVEY

\begin{tabular}{lccccc}
\hline & Factor 1 & Factor 2 & Factor 3 & Factor 4 & Factor 5 \\
\hline Factor 1 & 1,000 & & & & \\
Factor 2 & $-0,175$ & 1,000 & & & \\
Factor 3 & 0,329 & $-0,070$ & 1,000 & & \\
Factor 4 & $-0,118$ & 0,190 & $-0,107$ & 1,000 & \\
Factor 5 & $\mathbf{0 , 4 2 8}$ & 0,131 & 0,358 & $-0,080$ & 1,000 \\
\hline
\end{tabular}


TABLE 3

ROTATED FACTOR MATRIX OF THE FLOW EXPERIENCE SURVEY

\begin{tabular}{lccc}
\hline & Factor $\mathbf{1}$ & Factor $\mathbf{2}$ & $\mathbf{h} \mathbf{j}$ \\
\hline Subscore 1 & $\mathbf{0 , 8 1 8}$ & 0,112 & 0,778 \\
Subscore 3 & $\mathbf{0 , 6 9 3}$ & $-0,120$ & 0,406 \\
Subscore 15 & $\mathbf{0 , 6 5 8}$ & $-0,070$ & 0,386 \\
Subscore 4 & $\mathbf{0 , 6 3 4}$ & 0,141 & 0,517 \\
Subscore 8 & $\mathbf{0 , 4 2 0}$ & 0,077 & 0,217 \\
Subscore 11 & $\mathbf{0 , 3 7 8}$ & 0,305 & 0,358 \\
Subscore 5 & 0,258 & 0,212 & 0,170 \\
Subscore 2 & 0,223 & $\mathbf{0 , 7 8 6}$ & 0,854 \\
Subscore 13 & 0,023 & $\mathbf{0 , 4 7 9}$ & 0,241 \\
Subscore 7 & $-0,102$ & $\mathbf{0 , 4 5 0}$ & 0,164 \\
Subscore 6 & 0,009 & $\mathbf{0 , 3 8 7}$ & 0,154 \\
Subscore 10 & 0,154 & $\mathbf{0 , 3 0 6}$ & 0,167 \\
Subscore 12 & 0,143 & $\mathbf{0 , 1 9 8}$ & 0,090 \\
\hline
\end{tabular}

Note: Four subscores $(9,14,16,17)$ representing single items were excluded.

Using the NP50 programme, an item analysis was performed in respect of Scale 1 (Enjoyment) (Table 4) with 36 items and Scale 2 (Control of Consciousness) with 23 items (Table 5). During the iterative process, five items from Scale 1 (Enjoyment) were rejected. They were items $4,10,21,22$, and 33 . This scale yielded an overall reliability of 0,948 according to Cronbach's coefficient alpha. For the second scale, only one item, 36, was rejected during the iterative procedure. This scale yielded an overall reliability of 0,917 according to Cronbach's coefficient alpha. Both reliability coefficients are very high.

\section{Initial Recruitment Interview Schedule}

Like the Flow Experience Survey, the adequacy of the sample was determined by means of the Kaiser-Meyer-Olkin Measure of Sampling Adequacy (MSA). The value was $r=0,769$ and was considered adequate. The result of Bartlett's test of Sphericity was $\chi^{2}(45)=328,70 ; p<0.001$. This means that the variables are substantially mutually correlated and thus provides the necessary justification to continue with the factor analysis.

All ten subscales of the IRIS were intercorrelated (Table 6) and subjected to a principal factor analysis. Kaiser (1961) suggested that one should extract as many factors as there are eigenvalues larger than one. Three factors were extracted (Table 7) and rotated to simple structure with the aid of a Direct Oblimin rotation. The matrix of intercorrelations between the three factors appears in Table 8 . It was found that Factor 2 was poorly determined. Accordingly a two-factor solution was tried. Two scales were therefore formed. The reliability coefficient of the first scale was 0,75 and the second 0,46 according to Cronbach's coefficient alpha. Scale 2 was deemed to be too unreliable for inclusion in the study, therefore it was decided to collapse these two scales to represent a single factor (Table 9). This resulted in an overall reliability coefficient of 0,71 according to Cronbach's coefficient alpha for the total scale.

In order to determine whether the cognitive potential of the incumbents and the complexity of the work they perform are related, these variables were subjected to a chi-square analysis. The levels of job complexity were cross-tabulated against the levels of IRIS. Separate tabulations were made for the current, five, ten, and fifteen-year capability projections. From Table 10 it can be seen that there are statistically significant relationships between capability and job complexity, for all the capability projections into the future. These results lend support to Hypothesis 1.

The relationship between capability and job complexity becomes more meaningful if the chi-square is converted to a phi-coefficient. For current level of capability against job complexity, the chi-square yielded a phi- coefficient of 0,888 ( $\mathrm{p}<0,001)$. For the five-year capability projection, the phicoefficient was $0,665(\mathrm{p}<0,001)$. For the ten and fifteen year projections the phi-coefficients were $0,714(\mathrm{p}<0,001)$ and 0,755 ( $p<0,001$ ) respectively. This meant that $78,8 \%$ of the variance of job complexity can be attributed to individual capability at the current level. Similarly $44 \%, 51 \%, 57 \%$ of the variance of job complexity can be attributed to capability at the five, ten, and fifteen-year projection. These results lend further support to Hypothesis 1.

TABLE 4

ITEM ANALYSIS IN RESPECT OF THE FIRST SCALE (ENJOYMENT) OF THE FLOW EXPERIENCE SURVEY

\begin{tabular}{|c|c|c|c|c|}
\hline Item & $\overline{\mathrm{X}}_{\mathrm{g}}$ & $s_{g}$ & $r_{g x}$ & $\mathbf{r}_{\mathrm{gx}} \mathbf{s}_{\mathrm{g}}$ \\
\hline Q2 & 4,516 & 1,419 & 0,650 & 0,923 \\
\hline $\mathrm{Q} 4$ * & 5,656 & 1,031 & 0,275 & 0,284 \\
\hline Q6 & 4,534 & 1,589 & 0,601 & 0,955 \\
\hline Q7 & 3,913 & 1,489 & 0,667 & 0,993 \\
\hline Q8 & 4,689 & 1,488 & 0,497 & 0,740 \\
\hline Q9 & 5,447 & 1,279 & 0,336 & 0,429 \\
\hline Q10* & 5,714 & 1,045 & 0,282 & 0,295 \\
\hline Q12 & 4,273 & 1,728 & 0,449 & 0,776 \\
\hline Q13 & 4,795 & 1,225 & 0,601 & 0,737 \\
\hline Q15 & 5,112 & 1,383 & 0,739 & 1,022 \\
\hline Q17 & 5,099 & 1,366 & 0,630 & 0,861 \\
\hline Q20 & 5,116 & 1,329 & 0,460 & 0,611 \\
\hline Q21* & 5,280 & 1,184 & 0,324 & 0,384 \\
\hline Q22* & 5,776 & 1,129 & 0,297 & 0,335 \\
\hline Q23 & 5,298 & 1,400 & 0,549 & 0,768 \\
\hline Q27 & 4,379 & 1,639 & 0,714 & 1,171 \\
\hline Q30 & 3,770 & 1,708 & 0,511 & 0,872 \\
\hline Q31 & 5,770 & 1,169 & 0,366 & 0,428 \\
\hline Q33* & 2,472 & 1,714 & 0,018 & 0,030 \\
\hline Q35 & 4,137 & 1,575 & 0,500 & 0,788 \\
\hline Q37 & 4,534 & 1,662 & 0,760 & 1,263 \\
\hline Q38 & 5,037 & 1,360 & 0,602 & 0,818 \\
\hline Q40 & 5,031 & 1,575 & 0,530 & 0,835 \\
\hline Q42 & 4,814 & 1,590 & 0,748 & 1,190 \\
\hline Q43 & 6,025 & 1,072 & 0,538 & 0,577 \\
\hline Q45 & 4,677 & 1,653 & 0,524 & 0,867 \\
\hline Q46 & 5,199 & 1,350 & 0,498 & 0,672 \\
\hline Q48 & 4,614 & 1,450 & 0,702 & 1,018 \\
\hline Q50 & 4,783 & 1,611 & 0,667 & 1,075 \\
\hline Q52 & 5,037 & 1,274 & 0,721 & 0,919 \\
\hline Q54 & 4,627 & 1,799 & 0,726 & 1,309 \\
\hline Q55 & 5,130 & 1,352 & 0,670 & 0,906 \\
\hline Q58 & 4,366 & 1,556 & 0,743 & 1,156 \\
\hline Q60 & 4,522 & 1,370 & 0,513 & 0,703 \\
\hline Q61 & 4,478 & 1,333 & 0,701 & 0,934 \\
\hline Q62 & 4,137 & 1,539 & 0,518 & 0,798 \\
\hline Q63 & 4,565 & 1,564 & 0,643 & 1,006 \\
\hline Q64 & 3,814 & 1,621 & 0,667 & 1,081 \\
\hline Q65 & 4,025 & 1,581 & 0,709 & 1,121 \\
\hline Q66 & 4,733 & 1,495 & 0,665 & 0,995 \\
\hline Q69 & 4,037 & 1,874 & 0,440 & 0,824 \\
\hline
\end{tabular}

$\begin{array}{ll}\overline{\mathrm{X}}_{\mathrm{g}} & =\text { mean of item g } \\ \mathrm{s}_{\mathrm{g}} & =\text { Standard deviation of item } \mathrm{g} \\ \mathrm{r}_{\mathrm{gX}} & =\text { correlation of item g with total score } \\ \mathrm{r}_{\mathrm{gX}} \mathrm{s}_{\mathrm{g}} & =\text { index of reliability of item } \mathrm{g} \\ * & =\text { rejected items } \\ \text { Cronbach alpha } & =0,948\end{array}$


TABLE 5

ITEM ANALYSIS IN RESPECT OF THE SECOND SCALE (CONTROL OF CONSCIOUSNESS) OF THE FLOW EXPERIENCE SURVEY

\begin{tabular}{|c|c|c|c|c|}
\hline Item & $\overline{\mathrm{X}}_{\mathrm{g}}$ & $\mathrm{s}_{\mathrm{g}}$ & $r_{g x}$ & $r_{g x} s_{g}$ \\
\hline Q1 & 4,870 & 1,406 & 0,627 & 0,882 \\
\hline Q3 & 5,311 & 1,397 & 0,349 & 0,488 \\
\hline Q5 & 4,149 & 1,554 & 0,424 & 0,659 \\
\hline Q11 & 5,410 & 1,344 & 0,422 & 0,566 \\
\hline Q14 & 4,689 & 1,310 & 0,670 & 0,877 \\
\hline Q16 & 5,025 & 1,383 & 0,314 & 0,434 \\
\hline Q19 & 4,460 & 1,496 & 0,560 & 0,838 \\
\hline Q25 & 3,087 & 1,759 & 0,566 & 0,995 \\
\hline Q26 & 4,280 & 1,613 & 0,666 & 1,074 \\
\hline Q28 & 4,944 & 1,467 & 0,701 & 1,029 \\
\hline Q32 & 5,099 & 1,480 & 0,370 & 0,547 \\
\hline Q34 & 4,087 & 1,614 & 0,719 & 1,161 \\
\hline Q36* & 3,789 & 1,610 & 0,161 & 0,260 \\
\hline Q39 & 4,019 & 1,626 & 0,738 & 1,201 \\
\hline Q41 & 3,578 & 1,556 & 0,272 & 0,423 \\
\hline Q44 & 4,087 & 1,591 & 0,749 & 1,191 \\
\hline Q47 & 4,938 & 1,395 & 0,524 & 0,732 \\
\hline Q49 & 4,671 & 1,495 & 0,698 & 1,044 \\
\hline Q51 & 4,006 & 1,456 & 0,646 & 0,940 \\
\hline Q53 & 4,236 & 1,464 & 0,717 & 1,050 \\
\hline Q56 & 4,627 & 1,427 & 0,708 & 1,009 \\
\hline Q59 & 4,174 & 1,490 & 0,733 & 1,092 \\
\hline Q67 & 4,491 & 1,546 & 0,721 & 1,114 \\
\hline Q68 & 4,000 & 1,525 & 0,744 & 1,135 \\
\hline$\overline{\overline{\mathrm{X}}_{\mathrm{g}}}$ & \multicolumn{4}{|c|}{$=$ mean of item $g$} \\
\hline$s_{g}$ & \multicolumn{4}{|c|}{$=$ Standard deviation of item $\mathrm{g}$} \\
\hline$r_{g_{X}}^{\circ}$ & \multicolumn{4}{|c|}{$=$ correlation of item g with total score } \\
\hline$r_{g x} s_{g}$ & \multicolumn{4}{|c|}{$=$ index of reliability of item $g$} \\
\hline * Cronbach alpha & \multicolumn{4}{|c|}{$\begin{array}{l}=\text { rejected items } \\
=0.917\end{array}$} \\
\hline
\end{tabular}

TABLE 6

MATRIX OF INTERCORRELATIONS OF SUBSCALES IN RESPECT OF THE IRIS

\begin{tabular}{lrrrrrrrrrr}
\hline & $1 \mathbf{a}$ & $1 \mathbf{b}$ & 2a & 2b & 3a & $3 \mathbf{b}$ & $4 \mathbf{a}$ & $4 \mathrm{~b} / \mathbf{c}$ & $4 \mathbf{d}$ & $\mathbf{5}$ \\
\hline $1 \mathrm{a}$ & 1,000 & & & & & & & & & \\
$1 \mathrm{~b}$ & 0,158 & 1,000 & & & & & & & & \\
$2 \mathrm{a}$ & 0,177 & 0,080 & 1,000 & & & & & & & \\
$2 \mathrm{~b}$ & $-0,037$ & 0,124 & 0,052 & 1,000 & & & & & & \\
$3 \mathrm{a}$ & 0,377 & 0,079 & 0,388 & 0,147 & 1,000 & & & & & \\
$3 \mathrm{~b}$ & 0,150 & 0,283 & 0,249 & 0,241 & 0,328 & 1,000 & & & & \\
$4 \mathrm{a}$ & 0,193 & 0,120 & 0,288 & 0,160 & 0,500 & 0,197 & 1,000 & & & \\
$4 \mathrm{~b} / \mathrm{c}$ & 0,210 & 0,113 & 0,288 & 0,101 & 0,435 & 0,176 & 0,644 & 1,000 & & \\
$4 \mathrm{~d}$ & 0,029 & $-0,042$ & 0,273 & $-0,051$ & 0,269 & 0,080 & 0,168 & 0,290 & 1,000 & \\
5 & 0,271 & 0,129 & 0,338 & 0,134 & 0,478 & 0,234 & 0,405 & 0,446 & 0,125 & 1,000 \\
\hline
\end{tabular}

TABle 7

ROTATED FACTOR MATRIX OF THE IRIS (DIRECT OBLIMIN)

\begin{tabular}{lcccc}
\hline & Factor $\mathbf{1}$ & Factor $\mathbf{2}$ & Factor $\mathbf{3}$ & $\mathbf{\mathbf { h } ^ { 2 } \mathbf { j }}$ \\
\hline $3 \mathrm{a}$ & $\mathbf{0 , 6 7 9}$ & 0,316 & 0,209 & 0,605 \\
$\mathrm{a}$ & $\mathbf{0 , 5 3 2}$ & 0,149 & 0,098 & 0,315 \\
5 & $\mathbf{0 , 4 5 3}$ & 0,349 & 0,224 & 0,378 \\
$4 \mathrm{~d}$ & $\mathbf{0 , 3 6 7}$ & 0,162 & $-0,149$ & 0,183 \\
$1 \mathrm{a}$ & $\mathbf{0 , 3 5 5}$ & 0,101 & 0,149 & 0,158 \\
$4 \mathrm{~b} / \mathrm{c}$ & 0,340 & $\mathbf{0 , 7 3 4}$ & 0,082 & 0,661 \\
$4 \mathrm{a}$ & 0,291 & $\mathbf{0 , 7 2 1}$ & 0,188 & 0,639 \\
$3 \mathrm{~b}$ & 0,305 & 0,017 & $\mathbf{0 , 5 6 8}$ & 0,417 \\
$1 \mathrm{~b}$ & 0,053 & 0,043 & $\mathbf{0 , 4 2 5}$ & 0,185 \\
$2 \mathrm{~b}$ & 0,010 & 0,120 & $\mathbf{0 , 3 7 1}$ & 0,152 \\
\hline
\end{tabular}

TABLE 8

MATRIX OF INTERCORRELATIONS OF THE FACTORS IN RESPECT OF THE IRIS

\begin{tabular}{lccc}
\hline & Factor 1 & Factor 2 & Factor 3 \\
\hline Factor 1 & 1,000 & & \\
Factor 2 & $\mathbf{0 , 5 4 2}$ & 1,000 & \\
Factor 3 & 0,255 & 0,231 & 1,000 \\
\hline
\end{tabular}

TABLE 9

FACTOR MATRIX OF THE IRIS

\begin{tabular}{lcc}
\hline & Factor $\mathbf{1}$ & $\mathbf{h}^{2} \mathbf{j}$ \\
\hline $1 \mathrm{a}$ & 0,286 & 0,082 \\
$1 \mathrm{~b}$ & 0,409 & 0,167 \\
$2 \mathrm{a}$ & 0,435 & 0,189 \\
$2 \mathrm{~b}$ & 0,022 & 0,000 \\
$3 \mathrm{a}$ & 0,650 & 0,423 \\
$3 \mathrm{~b}$ & 0,069 & 0,005 \\
$4 \mathrm{a}$ & 0,710 & 0,504 \\
$4 \mathrm{~b} / \mathrm{c}$ & 0,780 & 0,608 \\
$4 \mathrm{~d}$ & 0,386 & 0,149 \\
5 & 0,548 & 0,300 \\
\hline
\end{tabular}

TABLE 10

Pearson Chi-square: Capability against job complexity

\begin{tabular}{lccc}
\hline Variable & $\chi^{2}$ & $\begin{array}{c}\text { Degrees of } \\
\text { Freedom }\end{array}$ & p \\
\hline $\begin{array}{l}\text { Current capability and job } \\
\text { complexity }\end{array}$ & 126,174 & 6 & $<0,001^{*}$ \\
$\begin{array}{l}\text { Projected capability (5 years) and } \\
\text { job complexity }\end{array}$ & 71,149 & 9 & $<0,001^{*}$ \\
$\begin{array}{l}\text { Projected capability (10 years) } \\
\text { and job complexity }\end{array}$ & 82,044 & 9 & $<0,001^{*}$ \\
$\begin{array}{l}\text { Projected capability (15 years) } \\
\text { and job complexity }\end{array}$ & 91,872 & 9 & $<0,001^{*}$ \\
\hline
\end{tabular}

*Statistically significant

Use was made of Pearson's product-moment correlation to identify the direction and magnitude of relationships between all the research variables. To do this, the IRIS and job complexity scores were standardised with a mean of 5 and a standard deviation of 2 . The difference between job level and current capability were computed. These correlations are given in Table 11. It is apparent from this table that the IRIS total score did not correlate significantly with the two flow factors. Furthermore, job complexity did not correlate significantly with either of the two flow factors. Therefore there was no support for Hypothesis 2. Although job complexity and capability are related, these two variables did not correlate with flow. There is thus no support for Hypothesis 3.

TABLE 11

CORRELATION COEFFICIENTS OF THE FLOW EXPERIENCE SURVEY (X1, X2) WITH THE IRIS TOTAL SCORE AND JOB COMPLEXITY

\begin{tabular}{lcc}
\hline & \multicolumn{2}{c}{ Flow Experience Survey } \\
\cline { 2 - 3 } & $\mathrm{X} 1$ & $\mathrm{X} 2$ \\
\hline IRIS total score & 0,059 & 0,036 \\
Job Complexity & 0,087 & 0,210 \\
\hline
\end{tabular}


Another objective of the study was to determine whether there are differences between the occupational categories in respect of flow experiences. For this purpose a Multivariate Analysis of Variance (MANOVA) was used. Similarly, to determine whether academic qualifications, and length of service made a difference in respect of flow experiences, MANOVA was used. To determine whether the different ethnic groups (Whites versus Blacks) differed from one another in respect of flow experiences, Hotelling's $\mathrm{T}^{2}$ was used. Furthermore, Hotelling's $\mathrm{T}^{2}$ was used to see if there were any gender differences in respect of flow experiences.

From the results in Table 12, the deduction can be made that there is not a statistically significant difference $(p=0,161)$ between the vectors of means of the four occupational categories, in respect of flow Factors 1 (Enjoyment) and 2 (Control of Consciousness). Therefore, there is no support for Hypothesis 2. The various academic groups do not differ statistically significantly from one another with respect to their flow experiences. Similarly, length of service within the organisation also makes no significant difference $(p=0,193)$ with respect to flow Factors 1 and 2. There was no statistically significant difference $(p=0,515)$ between the vectors of means of the Whites and Blacks in respect of the flow experience Factors 1 and 2 . There was also no statistically significant difference $(p=0,287)$ between the vectors of means of males and females in respect of the flow experience Factors 1 and 2. These findings do not support Hypothesis 4.

TABLE 12

SUMMARY OF MULTIVARIATE ANALYSES OF VARIENCE (MANOVA): GROUP DIFFERENCES IN RESPECT OF THE FLOW FACTORS

\begin{tabular}{lcccc}
\hline Variable & $\begin{array}{c}\text { Wilks' } \\
\text { Coefficient } \\
\text { Lambda }\end{array}$ & F & df & p \\
\hline 1. Occupational Categories & 0,939 & 1,552 & 6 and 292 & 0,161 \\
2. Academic Qualifications & 0,978 & 0,539 & 6 and 292 & 0,778 \\
3. Length of Service & 0,943 & 1,456 & 6 and 292 & 0,193 \\
\hline
\end{tabular}

Note:
Three MANOVA's are summarised in this table:

1. Occupational Categories (clerks, sales and services, professionals and

management)

2. Academic Qualifications (matric or less, diploma, degree, and post

graduate)

3. Length of Service (less than one year; more than one, but less than three; more than three, but less than five; more than five years)

An ancillary objective of the research was to determine if differences exist between occupational categories; academic qualifications groups; gender and ethnicity with respect to the IRIS total score. The mean scores of the four occupational categories in respect of the IRIS total score were compared and tested for differences with the aid of a one-way analysis of variance (ANOVA). The results of the ANOVA appear in Table 13. Having established that the four groups differed in respect of the IRIS total score, the group means were tested for differences with Scheffé's Multiple Comparisons Technique. The results of these comparisons are given in Table 14. From an inspection of this table, it can be seen that the professional occupations obtained the highest IRIS total score. These findings lend support to Hypothesis 5.

From an inspection of Table 15 it is clear that the means of the four academic groups (matric or less, diploma, degree and post graduate) differ in respect of the IRIS total score. From Scheffé's Multiple Comparisons (Table 16), it can be seen that the group with tertiary qualifications obtained the highest total score on the IRIS. These findings lend further support to Hypothesis 5. A t-test revealed no statistically significant difference between the means of males and females $(p=0,116)$ in respect of the IRIS total score. In like manner, no statistically significant difference was found between the White and Black groups $(\mathrm{p}=0,260)$. These findings do not support the expectation (Hypothesis 5) of statistically significant differences between ethnic groups and between gender groups in respect of the IRIS total score.

TABLE 13

ANOVA IN RESPECT OF OCCUPATIONAL CATEGORIES

\begin{tabular}{lrrrrr}
\hline Source of Variation & $\begin{array}{c}\text { Sum of } \\
\text { squares }\end{array}$ & df & $\begin{array}{c}\text { Mean } \\
\text { square }\end{array}$ & F & p \\
\hline Between Groups & 2674,809 & 3 & 891,603 & 41,230 & $<0,001^{*}$ \\
Within groups & 3395,141 & 157 & 21,625 & & \\
Total & 6069,950 & 160 & & & \\
\hline
\end{tabular}

* Statistically significant

TABLE 15

ANOVA IN RESPECT OF ACADEMIC QUALIFICTIONS

\begin{tabular}{lrrrrr}
\hline Source of Variation & $\begin{array}{c}\text { Sum of } \\
\text { squares }\end{array}$ & df & $\begin{array}{c}\text { Mean } \\
\text { square }\end{array}$ & F & p \\
\hline Between Groups & 1595,811 & 3 & 531,937 & 18,666 & $<0,001^{*}$ \\
Within groups & 4474,140 & 157 & 28,498 & & \\
Total & 6069,950 & 160 & & & \\
\hline
\end{tabular}

* Statistically significant

\section{DISCUSSION}

The aim of the study was to test Csikszentmihalyi's original flow model by determining whether the relationship between individual capability and job complexity are predictors of the flow experience. The first hypothesis is confirmed, as a statistically significant relationship was found between job complexity and individual capability at the current, five, ten, and fifteen-year capability projection. This supports the first hypothesis that people tend to gravitate towards work that is commensurate with their abilities.

TABLE 14

SCHEFFÉ's MULTIPLE COMPARISONS: COMPARISONS OF OCCUPATIONAL CATEGORIES IN RESPECT OF THE IRIS TOTAL SCORE

\begin{tabular}{lccccccccccccccccccc}
\hline & \multicolumn{1}{c}{ Means } & \multicolumn{4}{c}{ Standard Deviations } & \multicolumn{4}{c}{ Groups } \\
\hline Variables & A & B & C & D & A & B & C & D & A/B & A/C & A/D & B/C & B/D & C/D \\
\hline Total IRIS score & 20,13 & 22,16 & 26,30 & 32,07 & 3,64 & 2,69 & 5,08 & 6,56 & Not Significant & $<0,001^{*}$ & $<0,001^{*}$ & $<0,001^{*}$ & $<0,001^{*}$ & $<0,001^{*}$
\end{tabular}

* Statistically significant

Note:

$\mathrm{A}=$ Clerks

$\mathrm{B}=$ Sales and Services

$\mathrm{C}=$ Professionals

$\mathrm{D}=$ Management 
TABLE 16

SCHEFF'́, MULTIPLE COMPARISONS: COMPARISON OF VARIOUS ACADEMIC GROUPS IN RESPECT OF THE IRIS TOTAL SCORE

\begin{tabular}{|c|c|c|c|c|c|c|c|c|c|c|c|c|c|c|}
\hline \multirow[b]{2}{*}{ Variables } & \multirow[b]{2}{*}{ A } & \multicolumn{2}{|c|}{ Means } & \multicolumn{6}{|c|}{ Standard Deviations } & \multicolumn{5}{|c|}{ Groups } \\
\hline & & B & $\mathrm{C}$ & $\mathrm{D}$ & $\mathrm{A}$ & B & $\mathrm{C}$ & $\mathrm{D}$ & $\mathrm{A} / \mathrm{B}$ & $\mathrm{A} / \mathrm{C}$ & $\mathrm{A} / \mathrm{D}$ & $\mathrm{B} / \mathrm{C}$ & $\mathrm{B} / \mathrm{D}$ & $\mathrm{C} / \mathrm{D}$ \\
\hline & 21,46 & 22,67 & 26,93 & 28,98 & 3,25 & 4,47 & 6,93 & 6,21 & Not Significant & $<0,001$ * & $<0,001$ * & $<0,001$ * & $<0,001$ * & Not significant \\
\hline
\end{tabular}

* Statistically significant

Note:

Note:
$\mathrm{A}=$ Matric or less
$\mathrm{B}=$ Diploma

$\mathrm{B}=$ Diplom
$\mathrm{C}=$ Degree

$\mathrm{C}=$ Degree

$\mathrm{D}=$ Post graduate

There is no support for the second hypothesis, as the results did not support the expectation that employees from different job complexity categories will experience different degrees of flow, as documented in other research findings (Allison \& Duncan, 1988; Loubris, et al. 1996). It was expected that employees in more senior jobs, characterised by greater complexity and challenge, would be more likely to experience flow. Previous research used measures of job complexity that encompass factors such as autonomy, feedback, task identity and variety (Adelmann, 1987;Ganzach, 1998). These measures concern themselves with the job content, which may have been a more important contributor to the flow experience, than job complexity.

Although capability and job complexity are related, these variables did not correlate significantly with the two factors of flow. There is no evidence to support the third hypothesis. This finding suggests that there are other variables that affect the flow experience. These findings can be attributed to other confounding variables such as quantity of work and discretion (Lu, 1999). Other occupational characteristics, such as physical demands, affiliative contacts with co-workers, time pressures, temperature and cleanliness - variables not included in the present data set - would probably add to the non-significance of this relationship (Bumpus, et al. 1998; Deci \& Ryan, 1985). Further research should therefore examine the impact of job content and work environment on the experience of flow. Another possible reason for these findings is the nature of the relationship between skill and challenge being reliant on the perceptions of the employee (Csikszentmihalyi, 1975). This suggests that the objective structure, balance of skill and challenge, alone does not facilitate flow; the individual personally has to make it happen. The impact of interest in an activity should not be overlooked. The strength of an interest in an activity will affect the enjoyment derived from it. Therefore it may be possible to have optimal balance between capability and challenge but not the interest in the task. Interest may have therefore confounded the experience of flow in this sample. Further research should examine the influence of interest on the flow experience.

There is no support for the fourth hypothesis as no statistically significant differences were found between males and females, or cultural groups, or occupational categories with respect to the flow experience. Respondents with varied academic qualifications and length of service did not experience any statistically significant differences with respect to flow. From these findings it is suggested that all people derive the same psychological rewards from work, regardless of their gender, ethnicity, length of service, academic qualification or occupational category. Therefore, for this sample, the experience of flow appeared to be a universal phenomenon. However, Anderson, et al. (1996) found statistically significant differences between ethnic groups. This sample was not proportionally representative of different ethnic groups within the company. It is suggested that this study be replicated with a more representative sample. The research of Anderson, et al. (1996) also found significant differences between varied academic qualifications and the flow experience. A reason for this finding could be due to organisational culture placing greater emphasis on extrinsic rather than intrinsic rewards.

An ancillary objective of the study was to determine whether occupational categories, academic qualifications, gender and ethnicity produce significant differences in respect of the IRIS total score. There was no statistically significant difference between males and females or different ethnic groups in respect of the IRIS total score. This might imply culture fairness of the IRIS. However, statistically significant differences were found in respect of occupational categories and academic qualifications. It was found that those in higher occupational categories and those with higher academic qualifications had higher IRIS total scores. Therefore there was evidence to support the fifth hypothesis. The reason for these findings relates to the differences in cognitive capability. The IRIS is useful to determine an individual's potential for development in jobs he or she may be suited to. However, the IRIS is limited as it does not assess intelligence, personality or behavioural factors (Mauer, 1998).

It is the individual's perception of the complexity of the job and his/her perceived competence that essentially determines the flow experience. People create the experience of work, therefore it is suggested that flow is a subjective and psychological experience as opposed to an objectively determinable event. Flow makes sense for the individual, regardless of whether job complexity and capability are balanced. Further research should investigate the personality characteristics of those who experience flow frequently. The flow model is limited because it is impossible to explain the quality of the flow experience by reference to the objective conditions or the environment alone, or by reference to the person alone; only the interaction between the two yields the flow experience (Csikszentmihalyi (1975).

A number of possible limitations of the study have been identified. The limitations are primarily related to the measurement of flow. The flow questionnaire may not have captured the essence of the flow experience, but rather the more transient aspects. A further limitation to the study is the use of a convenience sample. Therefore, one should be careful not to generalise the findings as the participants came from one organisation. The sample was also drawn from an organisation undergoing significant changes within the external environment in which the company operates. In conclusion, the results of the study revealed that job complexity is related to capability, but these variables are not necessarily predictors of the flow experience.

\section{REFERENCES}

Adelmann, P.K. (1987). Occupational complexity, control, and personal income: the relation to psychological wellbeing in men and women. Journal of Applied Psychology, 72 (4), 529-537. 
Alderfer, C.P. (1972). Existence, relatedness, and growth: human needs in organisational settings. New York: Free Press.

Allison, M.T. \& Duncan, M.C. (1988). Women, work and flow. In M. Csikszentmihalyi \& I.S. Csikszentmihalyi (Eds) (1988). Optimal experience: Psychological studies of flow in consciousness. New York: Cambridge University.

Anderson, D.R., Crous, F. \& Schepers, J.M. (1996). Flow and quality of work life in a diverse workforce. Journal of Industrial Psychology, 22 (3)13-20.

Bandura, A. (1997). Self-efficacy: the exercise of control. New York, NY: Freeman.

Bumpus, M.A., Olbeter, S. \& Glover, S.H. (1998). Influences of situational characteristics on intrinsic motivation. Journal of Psychology, 132 (4), 451-463.

Carli, M., Delle Fave, A. \& Massimini, F. (1988). The quality of experience in flow channels: comparison of Italian and U.S. students. In M. Csikszentmihalyi \& I.S. Csikszentmihalyi (Eds) (1988). Optimal experience: Psychological studies of flow in consciousness. New York: Cambridge University.

Carraher, S.M. \& Chait, H. (1999). Levels of work and felt fair pay: an examination of two of Jaques' constructs of equitable payments. Psychological Reports, 84, 654-656.

Csikszentmihalyi, M. \& Csikszentmihalyi, I.S. (Eds) (1988). Optimal experience: Psychological studies of flow in consciousness. New York: Cambridge University.

Csikszentmihalyi, M. \& Jackson, S.A. (1999). Flow in sports: the key to optimal experiences and performance. Champaign, IL: Human Kinetics

Csikszentmihalyi, M. (1975) (2000 - 25 th anniversary edition). Beyond boredom and anxiety: Experiencing flow in work and play. San Francisco: Jossey-Bass.

Csikszentmihalyi, M. (1990). Flow: the psychology of optimal experience. New York, NY: Harper Perennial.

Csikszentmihalyi, M. (1993). The evolving self: the psychology for the third millennium. New York, NY: Harper Collins.

Csikszentmihalyi, M. (1997). Finding flow: the psychology of engagement with everyday life. New York, NY: Basic books.

Damrad-Frye, R. \& Laird, J.D. (1989). The experience of boredom: the role of the self-perception of attention. Journal of Personality and Social Psychology, 57 (2), 315-320.

Daniels, K. (2000). Measures of five aspects of affective wellbeing at work. Human Relations, 53 (2), 275-283.

Danna, K. \& Griffin, R.W. (1999). Health and well-being in the workplace: a review and synthesis of the literature. Journal of Management, 25 (3). 357-390. Retrieved October 30, 2000, from the World Wide Web: http://infotraccustom.com

Deci, E.L. \& Ryan, R.M. (1985). Intrinsic motivation and selfdetermination in human behaviour. New York, NY: Plenum.

Fisher, C. (1993). Boredom at work: a neglected concept. Human Relations, 46 (3), 395-415.

Ganzach, Y. (1998). Intelligence and job satisfaction. Academy of Management Journal. 41 (5), 526-540. Retrieved September, 28,2000 , from the World Wide Web: http://infotraccustom.com

Gemmil, G. \& Oakley, J. (1992). The meaning of boredom in organisational life. Group and Organisational Management, 17 (4), 358-370.

Gerhart, B. (1988) Sources of variance in incumbent perceptions of job complexity. Journal of Applied Psychology, 73 (2), 154162.

Ghani, J.A. \& Deshpande, S.P. (1994). Task characteristics and the experience of flow in human computer interactions. Journal of Psychology, 128 (4),381-391.

Hackman, J.R. \& Oldham, G.R. (1980). Work redesign. Reading, MA: Addison-Wesley.

Herzburg, F. (1966). Work and the nature of man. Cleveland: World Publishing.

Holland, J. L. (1985). Making vocational choices: a theory of vocational personalities and work environments. Englewood Cliffs, NJ: Prentice-Hall.
Jaques, E. \& Cason, K (1994). Human capability: a study of individual potential and its application. Falls Church, VA: Cason Hall.

Jaques, E. (1970). Work, creativity and social justice. London: Heinemann Educational.

Jaques, E. (1986). The development of intellectual capability: a discussion of stratified systems theory. Journal of Applied Behavioral Science, 22 (4), 361-383.

Jaques, E. (1989). Creativity in work. Arlington, VA: Cason Hall.

Jaques, E. (1996) (Rev. $2^{\text {nd }}$ ed.) The requisite organisation: a total system for effective managerial organizational and managerial leadership for the $21^{\text {st }}$ century. Arlington, VA: Cason Hall.

Judge, T.A., Bono, J.E. \& Locke, E. A. (2000). Personality and job satisfaction: the mediating role of job characteristics. Journal of Applied Psychology, 85 (2), 237-249.

Kaiser, H.F. (1961). A note on Guttman's lower bound for the number of common factors. British Journal of Statistical Psychology, 14 (1),1.

Kivimaki, M., Kuk, G., Elovaino, M., Thomson, L., KalliomakiLevanto, T. \& Heikkila, A. (1997). The Team Climate Inventory (TCI) - four or five factors? Testing the structure of the TCI in samples of low and high complexity jobs. Journal of Industrial and Organizational Psychology. 70 (4), 375-390.

Larson, R. (1988). Flow and writing. In M. Csikszentmihalyi \& I.S. Csikszentmihalyi (Eds) (1988). Optimal experience: Psychological studies of flow in consciousness. New York: Cambridge University.

LeFevre, J. (1988). Flow and the quality of experience during work and leisure. In M. Csikszentmihalyi \& I.S Csikszentmihalyi (Eds) (1988). Optimal experience: Psychological studies of flow in consciousness. New York: Cambridge University.

Loubris, S., Crous, F \& Schepers, J.M. (1995). Management by objectives in relation to optimal experience in the workplace. Journal of Industrial Psychology. 21 (2), 12-17.

Lu, L. (1999). Work motivation, job stress and employees' wellbeing. Journal of Applied Management Studies, 8 (11) 61-74.

Massimini, F. \& Carli, M. (1988). The systematic assessment of flow in daily experience. In M. Csikszentmihalyi \& I.S Csikszentmihalyi (Eds) (1988). Optimal experience: Psychological studies of flow in consciousness. New York: Cambridge University.

Mauer, K.F. (1997). Defence of the selection procedure used by the South African Breweries for executives and Grade $G, H$, and I managers. Pretoria: University of South Africa.

Mauer, K.F. (1998). An evaluation of the selection procedures used by $S A B$ (Beer Division) for the purpose of selecting BOP operators, supervisors, team leaders and process artisans, with comments on selected legal implications. Pretoria: University of South Africa.

Mauer, K.F. (2000, October). Some perspectives on CPA and IRIS research in South Africa. Paper presented at the Spring School Conference, Maccauvlei, South Africa.

McClelland, D.C. (1965). Power: the inner experience. New York: Irving-Halsted-Wiley.

McGregor, D. (1960). The human side of the enterprise. New York: McGraw-Hill

McIntyre, R.M., Yanusefski, A. M. \& Hamill. L. (1994). Toward a theory of leadership: the place of cognitive skills. Old Dominion University: Norfolk.

Novak, T.P. \& Hoffman, D.L. (1997, July). Measuring flow experiences among web users. Paper presented at Interval Research Corporation, Vanderbilt University. Retrieved March 14, 2001. From the World Wide Web: http://www.msn.com

Oldham, G.R. \& Cummings, A. (1996). Employee creativity: person and contextual factors at work. Academy of Management Journal, 39 (3)607-635.

Olivier, A. (1999). Reflections of work capacity and individual capacity: a practitioners guide to work theme audits and organisational mapping $\odot$. Brunel Institute for Social and Organisational Sciences. 
Privette, G. \& Bundrick, C.M (1987). Measurement of experience: construct and content validity of the experience questionnaire. Perceptual and motor skills, 65 (315-332).

Privette, G. (1983). Peak experience, peak performance, and Flow: a comparative analysis of positive human experiences. Journal of Personality and Social Psychology, 45 (6), 1361-1368.

Rossan, S. \& Baker, J. (1997). Original reliability studies of the Dixon's milk round interview schedule (Updated). Middlesex, Uxbridge: Brunel University.

Rossan, S., \& Topham, D. (1996). The assessment of capability: the reliability and validity of the CPA as a means of assessment. Unpublished paper.

Stamp, G. \& Retief, A. (1996). Towards a culture free identification of working capability: the career path appreciation. To be published in Venter, J., de Beer,
H. \& Tashe, B. (1996). Towards culture-free identification of leadership potential. Johannesburg: Knowledge Resources.

Stamp, G. (1988). Longitudinal research into methods of assessing managerial potential. (Technical report 819) US Army, Research Institute for the Behavioural and Social Sciences.

Stamp, G. (1991). Well being and stress at work. Employee Counselling Today, 3 (3), 3-9.

Stamp. G. \& Stamp C. (1993). Wellbeing at work: aligning purposes, people, strategies and structures. International Journal of Career Management, 5 (3), 1-36.

Wellner, A. \& Adox, D. (2000). Happy days (Positive Psychology movement). Psychology Today, 33 (3), 32-36.

Xie, J.L. \& Johns, G. (1995). Job scope and stress: can job scope be too high? Academy of Management Journal, 38 (5), 12881300 . 